\title{
Revisiting the Concept of Waqf: Its Maintenance, Issues and Challenges
}

\author{
HAYATULLAH LALUDDIN*, SAYED SIKANDAR SHAH HANEEF, MOHAMMAD TAHIR \\ SABIT HAJI MOHAMMAD \& MAYA PUSPA RAHMAN ${ }^{1}$
}

\begin{abstract}
Philanthropic endowment or wqaf represents a form of long lasting charity with potential profits or benefits meant for the spiritual and economical improvement of the society. This study attempts to revisit the concept of waqf by analysing its literal and technical meanings, its legitimacy in the light of the Qur'an and Sunnah. It also analysis some classical and contemporary views pertaining its conceptualization and traces its origin in the Islamic heritage. Istibdal, exchange of the waqf property, as a means of viability of waqf property and its relevant challenges are also dealt with. This paper is based on library research and use qualitative method. Having analysed, the relevant data the authors arrived at the conclusion that future efforts need to be made to develop the concept of waqf based on maqasid shari'ah while in tandem need to develop a universal and comprehensive vision of shari'ah based on its objectives. Both concepts must be revisited, reviewed, and revised to restore the dynamism of the concept of waqf hence, making it an effective tool for alleviation of the poverty and the distribution of wealth among the different sections of the society in equitable manner.
\end{abstract}

Keywords: Waqf, Istibdal, Economic development, Juristic schools, shari'ah

The motive for the establishment of waqf could be categorised primarily as religious one, for, religion functions as the main motivating factor for Muslim social and intellectual activities. Belief in the Day of Judgment and the anticipation of reward from God played decisive role in the establishment of charitable institutions and pious deeds. They resorted to performing everlasting good deeds under the sway of strong conviction and anticipation of reward in the afterlife. There are infinite instances of waqfs made by Muslims throughout history and which were equated with charity. In addition to expectation of reward, the growing of the social structure and its complexity in the early period of Muslim society, gave rise to formation of some charitable institutions to cater for the growing needs of the society. The main motive for the formation of waqf in the first and second centuries was to finance the jihad for the cause of God and enhancement of brotherhood (Babacan 1998). Thus, concern for attainment of the pleasure of God and not the worldly reward constituted the primary cause for the formation of the charitable foundations. By the passage of time and the expansion of the territories of Islam to other part of

\footnotetext{
${ }^{1}$ Hayatullah Laluddin* (Correspondent Author), Ph. D., Assistant Professor at the Department of Economics, International Islamic University Malaysia, Jalan Gombak, 53100, Kuala Lumpur, MALAYSIA. Email: hayatul@iium.edu.my; Sayed Sikandar Shah Haneef, Ph. D., Professor at the Dept. of Fiqh and Usul, Kulliyyah of Islamic Revealed Knowledge and Human Sciences, International Islamic University Malaysia, Jalan Gombak, 53100, Kuala Lumpur, MALAYSIA. Email: sayedsikandar@iium.edu.my; Mohammad Tahir Sabit Haji Mohammad, Ph. D., Assoc. Professor at the Dept. of Laws, Ahmad Ibraim Kulliyyah of Laws, International Islamic University Malaysia, Jalan Gombak, 53100, Kuala Lumpur, MALAYSIA. Email: tahiriiumedum@iium.edu.my; Maya Puspa Rahman, Ph. D., Assoc. Professor at the Dept. of Economics, International Islamic University Malaysia, Jalan Gombak, 53100, Kuala Lumpur, MALAYSIA. Email: mayapuspa@iium.edu.my
} 
the world hence, the social and economic development, waqf resumed a more comprehensive role. It became very common in the Muslim society and occupied an economic role of high significance. The prominence of its economic role in the later centuries, is attested to by the Ottoman State large scale establishment of waqfs. The establishment of the waqf was so common in the Ottoman State to the extent that one third of its cultivatable lands constituted waqf properties.

Legality of waqf institutions and their legitimacy can be construed from the primary source Islamic law; Qur'an which contains injunctions where the giving of alms and the sharing of wealth with others is highly encouraged. Therefore, waqf as a means of provision of sustainable benefits to the beneficiaries exemplifies the most viable and effective instrument for achieving such purpose. Sunnah, as the second source provide solid basis for legitimacy of waqf as there are several ahadith which explicitly state the legitimacy of waqf. From among the ahadith reflecting the legitimacy of waqf is the tradition narrated by Abu Hurairah highlighting the everlasting benefits of three types of deeds comprising recurrent charity, sadaqah jariyyah, beneficial knowledge, and pious offspring. Waqf fit most to the recurrent charity mentioned in the hadith, thus represent the legitimate type of act with multiple fold reward for its dedicator. The second evidence to the legitimacy of the waqf is the tradition related to Umar Ibn Khatab dedication of his land in Khaibar after consulting with the Prophet (p.b.u.h). Having proved the legitimacy of waqf and its everlasting effect we can conclude that seeking qurbah, nearness to God, constituted the driving force of Islamic medieval charity which was an integral part of Islamic ethic, and which was expressed through the use of terms qurbah (nearness to God) and thawab, (reward).

Consequently, waqf constitutes an essential ingredient of the Muslim society's culture and pervade all walks of its life. Thus, it contributes to the service of the public in various areas of development. It also resumed its role as the source of funding for Muslims over the centuries. Traditionally, waqf scope was very comprehensive as it covered almost all needs of life during the early period of Islamic civilization. It service covered a large spectrum of social needs without cost to the government. In fact, it played an intermediary role between central government and the localities in provision of public goods. This paper attempt to revisit the concept of waqf by analysing its literal and technical meanings, its legitimacy in the light of the primary sources of Islam; Qur'an and Sunnah. It also provides classical as well as contemporary views pertaining its conceptualization and analyses its origin in the Islamic heritage and its initial role as a charity, for the sake of attaining the pleasure of God and the reward in the hereafter, to that of evolved role of high economic significance, provision of most of the social service needs of the community. Istibdal, exchange of the waqf property, as means of viability of waqf property is also dealt with. This paper is based on library research and use qualitative method. The information and data collected from relevant primary and secondary sources are analysed to establish the shari'ah basis of the institution and the premises of its key principles. Having analysed, the relevant data the authors arrived at the conclusion that future efforts need to be made to develop the concept of waqf based on maqasid shari'ah while in tandem need to develop a universal, and comprehensive vision of shariah based on its objectives. Both concepts must be revisited, reviewed, and revised. All this is needed to restore the dynamism of the concept of waqf and hence, making it an effective tool for alleviation of poverty and ensuring the distribution of wealth among the different sections of the society in equitable manner.

\section{Semantic Analysis and Definition}

Waqf is originated from the Arabic word 'al-Waqf'. There are a series of literal meanings of waqf among which are; to stop (al-sukun) to prevent, (al-mana'a) and to suppress, or to detain (alhabs)(Ayub 1998). Al-habs could also be defined as to prevent (mana'uhu), to hold (amsakahu) and to detain (sajjanahu). Al-hubays the objective form of the al-habs means the type of property which is held with the intention of distributing or donating its benefits for a good cause. Thus, the words al-ahbas and al-awqaf, the plural of al-habs and al-waqf, respectively, reflect the same meaning which is to hold something from being consumed and distributing its benefit for the 
purpose of íbadah (Abu al-Fadl 1982). Among other meanings attributed to waqf are confinement or prohibition, while technically it is defined "holding certain property and preserving it for the confined benefits of certain philanthropy and prohibiting any use or disposition of it outside that specific objective" (Kahf 2015:2). Waqf is also called boniyad or habs in Iran and North Africa respectively (Cizakca 1998). It is also delineated as the immobilization of an owned property (hanbs al-áyn) for the purpose of worship (íbadah) or charity (tasadduq) by means of allocating the derived revenues from that property to the poor and the needy (Al-Khassaf 1904). Waqf therefore, could be understood to signify the donation of usufruct of a certain property for a beneficiary, the drive for which is motivated by an urge for fulfilment of some pious aim or some project of common utility (Kahf 2015; Hashim et al. 2014).

Muslim jurists from the well-known schools of jurisprudence also have expressed their views on the definition of waqf. For instance, Imam Abu Hanifah defined it as preservation or the up keeping of the original property belonging to someone else and giving its derived benefit to the designated need intended by the donor. The relationship between the donor and the endowed asset never cease as long as the endowed property exits. Thus, it could be viewed to provide an infinite source of reward and benefits to the donor and the beneficiary respectively. This everlasting effect of the endowment is possible when it is physical preserved and its benefits are distributed to the designated beneficiary. Similarly, Imam Malik defined waqf as the ownership of derived benefits from original asset given as endowment and giving them to the needy. Meanwhile, al-Shafií expressing his view pertaining the meaning of waqf, states that waqf is to keep the property that is capable of giving benefits and maintaining it in the same form and preserving it from consumption by the owner (Hakeem et al. 2016; Hashim et al. 2014).

From the preceding views pertaining the meaning and definitions of the waqf it became clear that philanthropic endowment or waqf represents a form of durable and long lasting charity which profits or benefits are meant for the spiritual and economical improvement and an overall welfare of the society.

In the contemporary context, waqf is also known as a charitable trust specially in those countries practicing common law. Trust is defined as a legal relationship between two persons where one of them is holding the property for the benefit of another (Mohd Ali et al. 2015). Whereas, waqf is defined as an Islamic endowment with the same objective as charitable trust. The uniqueness of waqf is due to its being a special kind of sadaqah (charity) from which the beneficiaries gain benefits to the exclusion of the donor himself (Babacan 2011). Thus, it differs from charitable trust where the donor is considered as one of the beneficiaries.

Consequently, waqf means "to protect something by preventing it from becoming the property of a third party" (Tahir \& Abdul Hamid 2014:14). However, the concept of waqf embodies any property which benefits are used for a charitable purpose be it public or specific in according to the principles of Shariáh (Jasni 2013). It is also perceived to mean an eternal dedication of moveable or immovable asset or property for a good and charitable cause.

\section{Origin and History}

Waqf or endowment is not a new or recent phenomenon for it has been in existence in human society since long time ago. Although some views trace the origin of waqf to pre-Islamic Arabia Roman or Byzantine era there is no authentic evidence to this effect. For the purpose of our study the discussion of the level of interaction between different civilizations is avoided here, for it requires another study which is beyond the scope of this paper. In tracing the origin of the waqf focus is made on its Islamic origin. The origin of Islamic endowment or philanthropic foundations can be traced back to the Islamic heritage. Muslims since the early stages of their Islamic social and intellectual life were driven by their belief in the day of judgement to form institutions or do pious deeds. Under the influence of their strong belief in the reward in hereafter they were motivated to perform everlasting good deeds in anticipation of gaining the pleasure of God. Thus, religious factors played crucial role in establishing philanthropic foundation or waqf which is a voluntary, permanent, and irrevocable dedication of a segment of one's property to God, with the 
stipulation of maintaining its corpus for, being belonged to God. The first instance of the waqf in Islamic history is the waqf land in Madinah on which the Quba mosque was built. It was built in the first year of hijrah upon the arrival of the Prophet (p.b.u.h) (Babacan 2011; Ariffhidayat 2010). Waqf, regardless of its type; being (khayri) or family (ahli or dhurri), represents an excellent type of sadaqah, for its being dedicated to the cause of God (fi sabil llah) hence becoming a property of God (haqq Allah).

Due to the spread of Islam throughout western Arabia, Northern Africa and the East (currently including Iran, Afghanistan and India), in the early period of Islamic history during Umayyad and Abassid reign, Muslim societies attained high level of development and sophistication. Therefore, to cater for the needs of this complex social structure Muslims established some charitable institutions. The early examples of awqaf, with its judicial basis, could be observed in the first and second centuries of Islam. The motive behind Muslims establishing such charitable foundations was to finance the jihad (struggling in the cause of God). Thus, financing of the fighters in the cause of God and Muslim brotherhood, constituted the main function of waqf at the early period of Islam (Babacan 2011; Gil 1998). This shows that the early Muslims established endowment with the sole objective of getting God pleasure and not any worldly reward. However, in the later period waqf, regardless of it motives, become very common in the Muslims societies and resumed an economic role of high significance. A good example is provided by Ottoman State where awqaf were very common and comprehensive to the extent that one third of its cultivatable lands, including the Middle East and the Balkan, constituted waqf properties (Babacan 2011).

Consequently, waqf represents an excellent example of sadaqah. There are several instances of the historical evidences indicating waqf as the excellent example of the embodiment of the sadaqah. Among the earliest known surviving waqf inscriptions and documents to this effect is an endowment inscription from 301/913-14, in the town of Ramala in Palestine, equating the act of endowment with sadaqah. The subject matter of the endowment in this case consisted of an urban commercial property a hotel (funduq) with dual function of a business premise and residential place or motel. The donor of this type of property as a waqf, was called Faiq. From the inscription on the endowed property, it is clear that he had endowed the property as charity, the purpose behind which was to seek nearness to God and His forgiveness. Another example, of the same nature is that of the pious endowment made by a Christian woman from Fayyum in Egypt in 948, which was made in support of a church at a monastery complex in the desert. This type of endowment was formulated according to Islamic law. Although in this case the endowment came from a Christian community, this is indicative of the commonality of the concepts of charity and pious endowments across the three monotheistic religions. And here we see a Christian woman to have found Islamic law as a suitable legal framework for expressing her piety and religious faith. Prior to this was another draft of a pious endowment document of the ahli type, also from Fayyum, created within a local Muslim family of textile merchants, which final beneficiaries are not mentioned (M. Sharon 1966).

Evidently, in the classic time it was a common phenomenon to equate the pious endowment with charity. This is widely evident from other pious endowment deeds such as the pious endowment made by al-Hakim in 1010 which he referred to as charity. It was mainly set up for the purpose of supporting mosques and a learning institution (dar al-hikma) in Cairo. Similarly, the Fatimid vizier, Talai ibn Ruzzik, in 1159 created pious endowment in support of the ashraf, (nobles class) living in Fustat-Cairo and Arabia (Lev. Yaccov 1936).

\section{Legitimacy of Waqf}

The Qurán does not specifically mention waqf but sanctions and encourages the giving of alms. The injunctions pertaining alms giving provide the basis from which the legitimacy of waqf can be constructed. (Ibrahim \& Ibrahim 2013; Ahmad et al. 2015) Among the injunctions encouraging charity and the promise of great reward by Allah (s.w.t) are: 
"Those who spend their wealth (in Allah's cause) by night and day, in secret and public, they shall have their reward with their Lord. On them, shall be no fear, nor shall they grieve" (Qurán 3:274) and:

"By no means shall you attain Al-Birr (piety, righteousness- meaning Allah's reward, i.e. paradise), unless you spend (in Allah's cause) of that which you love; and whatever of goods you spend, Allah knows it well" (Qurán 3:92) and:

"Verily those who give sadaqat (i.e. zakat and alms), men and women, and lend a good loan, it shall be increased manifold (to their credit), and there shall be an honourable good reward (i.e. paradise)" (Qurán 57:18).

Delving deep into the meaning of the above Quránic verses we can conclude that the sharing of wealth with other by means of donation and alms giving is highly encouraged in Islam. Therefore, waqf as a means of provision of sustainable and perpetual benefits to the beneficiaries represents the most effective instrument for achieving such a purpose.

The legitimacy of waqf is not only derivable from the Quránic verses sanctioning and encouraging the giving of charity and alms. There are several hadiths of the Prophet (p.b.u.h) that provide a clear cut basis for the legitimacy of endowment or waqf (Cizakca 1998; Babacan 2011; Ibrahim \& Ibrahim 2013). One of the tradition of the Prophet (p.b.u.h) to this effect is his wellknown hadith narrated by Abu Hurairah;

"When a man dies all his acts come to an end, but three; recurring charity (sadaqah jariyah) or knowledge (by which people benefit) or a pious offspring who prays for him" (Al-Tirmidhi 1967:660) cited in Ibrahim \&Ibrahim 2013; Mohd. Ali et al. 2015).

This hadith provides a clear cut basis for legitimacy of the waqf. The recurrent charity, as stated in the hadith, means when a person gives some of his belonging, property or land for the use of other without expectation of any return from them it becomes continuous sadaqah that benefit the beneficiaries. Allah will reward him for such an act of recurrent charity that benefit him in afterlife. The expectation of the reward from Allah (s.w.t) in the afterlife by the Muslims lead to tremendous zeal and interest among them in giving their properties especially land for waqf. Thus, the enthusiasm and the faith in this hadith among the Muslims was so strong that three quarters of the land of Arabia and other territories was dedicated to waqf. The second tradition that support waqf is that concerning Umar Ibn Khatab when he went to the Prophet (p.b.u.h) and said:

"Oh Messenger of Allah! I got a land in Khaiber. Which is the most precious property I have ever had. What do you advise me to do with it?" The Prophet (p.b.u.h) said, "If you want you can make habs on (bequeath) it, and give it as sadaqah (charity) with the condition that it should not be sold, bought, given as a gift or inherited" (Sahih Muslim Hadith:4006; Sunan An-Nasa'i Hadith: 3681).

Umar complying with the advice of the prophet (p.b.u.h) gave it as a charity for the poor, relatives, slaves, wayfarers and guests. However, there is no harm if the person in charge feed himself or his friend from it for free without profiting. Cited in (Babacan 2011; Kahf 2014).

\section{The Essence of the Concept}

Two important elements of the concept of waqf need noting: the perpetuity of the donated property and the object of the donation on one side of the coin, while on the other the effort by the nazir of the waqf to keep the waqf property exist in perpetuity. The first two will be discussed under the scope and beneficiaries of the waqf while the second will be discussed under the conception of istibdal or substitution of old waqf property by a new one.

\section{Scope and Beneficiaries of Waqf}

The perpetuity of the object and subject matter of waqf can be understood from the hadith of the Prophet (p.b.u.h). As it became clear from the hadith, Umar had dedicated his land for the waqf by surrendering its produce for the above mentioned philanthropic purposes. At the meantime, he prohibited its beneficiaries from giving it away or inheriting or selling it. Hence, waqf could be 
classified as a continuous charity which benefits Muslims even after death. It is therefore, imperative to bear in mind that the creation of waqf must be for a purpose which is in line with principles of Sharia'h. Thus, the creation of waqf to promote black magic, deviant teaching etc. are strictly prohibited. This prohibition also includes the payment of interest along with the principal payment of debt as practiced by government nowadays. Thus, waqf plays a crucial role in provision of most of the social service needs of the community (Abdel Mohsin \& Magda 2009). Guided by Islamic religious principles, institutions of awqaf (endowments) represent the constant essential ingredients for economic circulation and re-circulation of surplus. Hence, it is by means of endowments that wealth could be transferred from the rich to the poor with the objective of eradication of poverty or at least its alleviation. The revenues generated from awqaf investments could be used positively in targeting specified areas with positive social impact and added-value to society.

\section{The Subject of Waqf}

Waqf institutions could indeed serve variety of purposes, but regardless of whatever purposes the pious endowment served, the deed is perceived in religious terms as seeking nearness (qurbah) to God. This is done through dedicating a property as a sadaqah for the sake of obtaining a reward from God in the afterlife. Such motivation was deeply ingrained in the ethics of Islamic medieval charity which constituted piece and parcel of the lives of those expressing their feelings through the use of the terms qurbah and thawab. There are overwhelming epigraphical evidences to this fact cutting across ethnic, religious, and language differences that characterized and distinguished Islamic medieval societies. Some of the examples illustrating the wide dissemination of this idea were the inscriptions on mosques and law colleges, stating the purpose of the establishment of those institutions to be the quest for thawab, reward and qurbah, nearness to God. Even, some waterwheels and an arsenal were also established for the same purpose. These two terms remained unchanged, despite the wide and diversified range of the institutions established. The underlying reason for their establishment was clearly mentioned to be the quest for qurbah, nearness to God and thawab, reward. For instance, the concept of reward for a good deed was inscribed on the gates of Cairo the drive for which is seemed to be inspired by the Quránic teachings sanctioning benevolence to the poor, the widows, the orphans, and the wayfarers (Lev. Yaacov 2005).

The unique concept of waqf prescribed by the Prophet of Islam and understood by the leading scholars of Islam has resulted into the popularity of waqf and the sustained contribution of the donations as well as the sustainability of donated properties. The conceptualisation of qurbah and sadaqah seem to have further contributed to the donation of the best of donor's properties and the high number of donations by pious Muslims, regardless of being poor or rich. The four leading schools of Fiqh have recognised the concept of perpetuity of the waqf among whom some restricted the concept such as Imam Abu Hanifah and Imam Muhammad while others broadened it. Among the latter, Imam Malik and his followers have allowed almost any sadaqah that the donor wished to call it waqf, while Imam Abu Yusuf and Imam Shafi'i stood between the above two groups. The latter allowed the donation of moveable and immoveable properties with less restrictions compared to that imposed by Imam Muhammad. They both did not allow revocation of waqf though. This irrevocability of waqf declaration, whether the subject of it is land or other types of goods, would be understood as perpetuity. They did not permit temporary waqf as was allowed by Imam Mallik and did not prohibit the donation of animals as was pronounced by Imam Muhammad. As time passed the perpetual and high number of donations contributed to distribution of wealth and the provision of public good to the society.

\section{The Object or The Purpose of Waqf}

Except for Imam Abu Hanifah and a few other earlier scholars, almost all schools of Islamic law agree on the perpetuity of the object, cause, and purpose of waqf. Both waqf khari and ahli should be perpetual. In other words, whenever the donation of property is made for a cause that is short 
lived, and temporary, Muslim jurists by implication recognise the donation to be for a cause that would never cease to exist. For instance, if the property is for the benefit of specified people or a group of them, it is presumed that at the end the property would go to the poor. For, they assumed the existence of poor people anywhere and at any point of time.

Waqf constitutes an essential ingredient of the Muslims society's culture and pervade all walks of its life hence, contributing to the service of the public in various areas of development. It has also become a source of funding for Muslims over the centuries, due to large endowments (awqaf) made by the prophet (p.b.u.h) and his companions. As Magda et al. (2016) has pointed out waqf scope was very comprehensive, for it covered almost all the needs of life during the early period of Islamic civilization. Its scope was not confined to provision of a single need of the society. It service covered a large spectrum of the social needs, such as health care, education, basic infrastructure, business and commercial activities, job creation, provision of food and shelter for hungry and homeless, and assistance of agricultural and industrial sectors without any cost to the government. Babacan (2011) has rightly observed the role of awqafs to be acting as intermediaries between central government and the localities in provision of public goods. Therefore, waqf being a charitable act of the highest degree, covered a large circle of beneficiaries ranging from the poor and needy to mosques, small communities of relatively well-off scholars, and mystics living in their lodges. Thus, the beneficiaries of waqf consisted of diverse groups and included professors of law some of whom were very well paid, students, preachers, and leaders of prayers as well as the low paid staff of mosques and law colleges. Lev Yaacov (2005) alludes the establishment of endowments for congregational mosques, law colleges, and lodges for mystics, to a complex set of reasons often reflecting political purposes, religious policies, piety, and the founders' quest for glory. However, one should bear in mind that these were religious institutions and were not designated for social relief. Unlike these religious institutions there existed other institutions of social nature and were meant to serve the poor and needy. They comprised of the hospitals, lodges for aged women, widows, and the poor, and Qur'anic schools for orphans.

\section{Exchange (Istibdal) as a Means of Viability of Waqf Properties}

As some of the endowments, especially those involving lands and immovable property, by the passage of time lost their productive use and became obsolete, this posed a serious challenge to the jurists. Therefore, they devised the concept of istibdal as a response to this challenge and as a means of preserving the viability of waqf properties. Istibdal or exchange refer to selling the land waqf with no potential of development and then buying another land which has the potential for development. Thus, istibdal effective application necessitates the involvement of innovation and mergers with other waqf products that are suitable to increase the potential success of istibdal (Hasnol \& Zam-Zam 2007; Hassan N. et al. 2018). Thus, the concept of istibdal, exchange of waqf properties, must have been practiced widely, since many references to such cases appear in the literary sources. As a legal mechanism, it played important role in ensuring the economic viability of waqf properties by allowing some changes, in respect to composition and location of these properties, in response to the changes in urban and rural economies. However, like any other legal-economic device, it was subject to misuse, therefore, some judges refused to approve requests for exchanges (Maqrizi 1943).

During the reign of Mamluk Sultans, istibdal emerged as a topic high on the public agenda, and contemporary sources referred to it frequently. Some of the istibdal of waqf properties were carried out by Barquq- Al-Malik Az-Zahir Sayf ad-Din Barquq (ruled 1382-1389 and 1390-1399) and was the first Sultan of the Mamluk Burji dynasty of Egypt. Similarly, in 826/1422-23, sultan Barsbay (1422-38) carried out istibdal of waqf properties by taking over the shops and commercial properties (fanadiq) which had been initially endowed for a law college. A year later he transacted another exchange practice by taking over properties endowed for the Holy Cities of Arabia -Macca and Madina- and the ransom of war prisoners. The loss of economic value, and the claim that the new property given will serve better the charitable causes stipulated in the original endowment, were regarded as the main reason for such exchange. Lev. Yaacov (2005) 
seems to agree with this view by assuming the possibility of depletion of pious endowments due to deterioration of their properties. He considered the replacement of the ruined waqf properties with the new ones by the Sultan beneficial to both sides. Unlike the directors of the depleted endowments, the Sultan had the ability to revive and develop the ruined properties due to having access to the economic means for the purpose.

However, it is also possible that the istibdal may have been used here as an excuse for acquisition of desirable properties while offering little, if anything, in exchange. This notion is overwhelmingly supported by fourteenth-century judges' strong objection to the demands of Mamluk Sultans and Emir in acquiring properties for their own waqf foundations through istibdal. However, the judges showed some measure of leniency during the fifteenth century by adopting more flexible practices and complying with the demands of the Mamluk ruling elite. Due to the lack of sufficient literature dealing with istibdal within the wider context of the pious endowment institution, it is advisable to avoid hasty conclusions. Miriam Hoexter (1995) for example, held istibdal to have made a positive contribution with regard to the management of the Pious Endowment for the Holy Cities of Arabia and in Ottoman Algiers.

Considering the inviolable nature, of the pious endowments, the judges were faced with a dilemma when they were asked to nullify pious endowments or authorize questionable istibdal transactions. However, when the nullification of pious endowments was necessitated due the needs of the Holy War or was presented as such, the judges would always support the regime. For instance, the judges instantly agreed to Saladin's request to nullify the pious endowments of Badr al-Jamali and use it for the expense of Holy War. Similarly, his request for transfer of money from the Office of Zakat to the Office of the Navy to finance the war for Acre was promptly fulfilled. In 789/1387-88, the judges also gave green light to Mamluk regime to use zakat money for military purpose due to being faced with the Mongol threat in Syria. They also, authorized the seizure of one year's income of pious endowments from the legal beneficiaries (Ibn Furat 1939). In other cases, Judges and jurists complied with the request of powerful Mumluk Emirs to nullify the pious endowment made by other Emirs. Casting doubt on the origin of the endowed property was used as a legal tool for the nullification of the pious endowments. This was done by casting doubt on the endowed property whether it was really a private property (mulk) or it was state property transferred in some doubtful manner into the possession of those who had endowed it. This, as has been noted by Maya Shatzmiller (2000) had negative impact on the endowments made by the fourteenth-century Marinid rulers of Morocco, hence leading to their nullification by the jurists.

Subsequently, prudent rulers, including the most powerful ones, realising the immense significance of this legal requirement; private ownership (mulkiyyah) of the endowment, spared no efforts in fulfilling this legal requirement when setting up pious endowments. It was therefore made a legal requirement to include in the documentation of endowment deed certain statements, testifying to private ownership of the endowed property. Despite the stipulation of such measure, the issue of mulk presented the skilful jurist with many possibilities of undermining the legal basis of a pious endowment. Whereas in other cases, where the judges own interest were at stake, they strongly defended the pious endowment against the seizure by the authority. Henceforth, attempts to exploit pious endowments made for the support of urban religious institutions affiliated with jurists, were met with strong opposition (Lev.Yaacov 2005).

Eventually, the debate between the rulers and jurists/ judges, in respect of endowment, led to the culmination of a conflict in 780/1378-79, when Barquq, assembled judges and the people of the religious establishment and complained to them about the large size of endowment lands and sought a way of nullifying these endowments. His contention was that the lands endowed for mosques, law colleges, lodges for the mystics, the sons of Sultans and Emirs, and alrizaq al-ahbasiyya, (lands in the provinces endowed in support of mosques in the rural areas, lodges for mystics in the villages, and other charitable purposes) had reached to such proportions that had effected the army negatively. A heated argument followed Barquq's speech, yet the judges and the people of religious class were able to hold their ground against Barquq and did not yield to his demands. Despite all this, some of the lands belonging to the pious endowments were dissolved, and were given to the soldiers. This was only one incident in the long conflict between 
the state's interests and the expansion of the pious endowment system. In 838/1434-35, the sultan in order to exert his control over the endowed properties, appointed the Shafi'i chief judge to inspect the pious endowments of law colleges and lodges for mystics, but it turn out the way not to be pleasing to him as the judge had no intention of pleasing the Sultan. The whole attempt ultimately ended in a fiasco, to the great relief of the people who might have been affected by the outcome of the inspection (Maqrizi 1943).

Even though the concept of istibdal was misused by the Mamluk Sultans its viability as a tool for financing the development of waqf property cannot be denied. It has played extremely significant role in the development and enhancing the value of waqf property in the contemporary context of the Muslim society. For example, it has been practiced in Malaysia and Singapore with pretty good and encouraging results. Malaysian states of Pulau Pinang, Federal Territory, Selangor, Perak and Melaka have practiced istibdal through their Islamic Religious Councils. For example, Pinang state have a few waqf properties of a high value among which is waqf al-Mashoor. This land was originally allocated for the construction of a religious school. Since the land was located in the administrative centre and main business hub, the state government made and agreement with Islamic Religious Council to substitute the land with another piece of land along with some compensation. The agreement was signed and 30 acres of land in Balik Pulau was given as a substitute for the waqf property in addition to RM6 Million for the construction of the religious school (Hisham et. al. 2013; Ahmad et. al. 2015). Similarly, Singapore Islamic Religious Council (MUIS) resorted to the implementation of the concept of istibdal to substitute the Madarash Al-Maarif Al-Islamiyah with a new building. Since the Madrasah was located in a prime area of the city and needed more space and renovation due to the increased number of the students, it was therefore reallocated to another venue. The exercise to reallocate the Madrasah to a new place was economically beneficial, hence, giving it a new lease of life with new building and facilities without incurring high cost and borrowings to construct the building (Shamsiah 2010). Thus, a well-planned implementation of istibdal is not only instrumental in development of the waqf property and enhancing its value, it could also play a crucial role in eradicating poverty and uplifting the socio-economic status of the Ummah.

Admittedly, the use of istibdal as a means of development of waqf property for the purpose of socio-economic development is a challenging issue. The first challenge pertaining the implementation of istibdal is the disagreement of the jurists, for they have varying views pertaining its application. This could be attributed to the unavailability of any direct reference to istibdal either in Qurán or in the Sunnah (Jasni 2013). Some jurists acknowledged its implementation in the cases of waqf estate being ruined or its land being barren or a mosque being abandoned or destroyed, and there is no means of their construction (Tahir \& Abdul Hamid 2006). In these situations, istibdal could be used to sell the waqf property or replace mosque's land with another property for the purpose of development. Those jurists not agreeing with istibdal argued that waqf property is perpetual and its retention should be continued for the purpose of piety, religion and charities, in order to benefit the recipients of its income or service. Therefore, this goal could only be attained by not allowing its exchange for whatsoever reason (Jasni 2013). This is because the exchange of waqf property is not in line with the everlasting, perpetual and not changeable nature of waqf. For, the public waqf property is no more owned by the endower and its ownership is transferred to Allah. Its sell, transfer, disposition, exchange or inheritance is prohibited by the Prophet (p.b.u.h) (Ayub 2003).

Furthermore, Imam Malik prohibits the exchange of immovable waqf property, unless the maslahah or public needs of society, such as the expansion of the mosque compound the cemetery and public road, dictate it, or it is being taken by force by state authority for the purpose of economic development (Zuhaily 1989). Other jurists support the idea of exchanging the waqf property with another property, if it is no more conducive to the welfare of the recipients and its exchange could secure the continuity of its benefit to the beneficiaries. Mardawi (1956) who is a Hanbali jurist represents this group. He contends that waqf property cannot be sold except in the case of its failure to generate any benefits. Once it is sold the proceeds of the sale should be used for buying another property. He applies the same line of argument with regard to a horse 
dedicated as waqf for jihad, when it is no more fit for battle, it can be sold for purchasing another one. Ibn Taymiyyah (2000) deems it necessary to sell waqf property if it lead to definite gain. Thus, based on his view the exchange of waqf property is permissible if it grantees benefits to beneficiaries. Moreover, additional amount of money could be added to the value of the sold waqf property to enhance the socio-economic welfare of the recipients. (Ibn Qudamah 1999). In sum, as Hamad (1993) holds, majority of Malikis opposed istibdal with the exception of a small number of them who accept it. Whereas, in case of the Shafi'i jurists some are opposing substitution of waqf property and other allow it. The Hanbalis consider substitution of waqf property permissible even if it is consisting of mosques which is ruined and is needed to be substituted. On the other hand, Hanafis view istibdal to be permissible for, it constitutes a mode of financing the development of the waqf property. The disagreements of the jurists pertaining istibdal have a strong bearing on the development of waqf properties as it would reduce the source of fund for the socio-economic development of the society.

The second challenge posed by istibdal is that it exposes waqf property to various risks such as corruption, expropriation and mismanagement. Notwithstanding some of the merits of the istibdal especially when high value waqf properties are sold to develop other waqf asset with the potential of generating sufficient fund for financing the socio-economic development, it still requires the waqf institution to adopt the best management practices to ensure transparency and accountability. Thus, there is a contextual dimension to the effectiveness of this method. Its use may not be suitable for some Muslim countries with lower income, where waqf management are involved with wide spread abuse of waqf property due to the lack of transparency and accountability. There is a strong possibility that if they are allowed to substitute waqf property, they will take advantage of it as a legal justification for expropriation of waqf asset and its abuse. The third challenge with regard to the implementation of istibdal is that of the existing stringent waqf related laws, in some countries, which make the replacement or sale of the waqf property very difficult. This can be regarded as another huge hurdle to the implementation of the istibdal for the development of waqf property.

\section{Discussion}

Looking at the existing literature, one observes the progress in the scholarly thought throughout the history of waqf. From the beginning of the theorisation of the Shari'ah texts and reports, the divergence of thought was based on literalist as well as logical and objective based approaches. These we may categorise based on the view of al Shuraih, Imam Abu Hanifah, and Imam Muhammad, and that of Imam Malik, Imam Abu Yousuf, and Imam al Shafi'i. The former group seems literalist on one hand and logical (qiyasi) on the other. However, the second group could be viewed literalist and objective based and then logical. As time passed the views of Imam Muhammad seem to have influenced many subsequent scholars, including those in other schools in the area of perpetuity of the subject matter of waqf. This influence somehow impacted the further progress of waqf and its contribution to the development of different sectors of society and the state.

The prevailing trend among the contemporary scholars is to make the institution of waqf a universal tool for the development of all walks of humanity without any discrimination based on place, time, and other bases of tribalization. This is a noble aim, and is perfectly in line with the hadith of the Prophet (p.b.u.h). However, the different scholastic approaches or the loyalty to a particular school of thought make these contemporary trends less convincing for those who still insist on faithfulness to a particular madhdab. The recurrent thought expounded by contemporary scholars is that the concept of waqf is ijtihadi as there is no compelling reasons why one must be rigid about the understanding of waqf. This makes us argue against rigidity and encourages to emphasize once again on the view of scholars such as Imam Malik, Abu Yousuf, and Imam Shafi'i.

The above opinions of the scholars need further development on one hand and removing of obstacle thereto on the other. The concept of perpetuity originated in the hadith of the Prophet 
(p.b.u.h) has been developed by the Muslim scholars in such a way that can open the door for the creation of fair and prosperous Muslim society. Though this trend was diverted from its aims throughout subsequent generations, with some exceptions in the history, the contemporary scholarship has been successful in the understanding of the early trend and has thus far achieved limited success around the globe. Nevertheless, two main issues, as discussed above, may still slow down the current trend, if they are not tackled in the future. These two issues are the complacency with the limited conceptual progress achieved and the lack of transparency in the use of the existing waqf funds. The conceptual difficulty is seen in the discussion of the goals of waqf that circle around economic need and necessity of the people. The second issue is historic which may lead to the loss of interest in the revival of the institution of waqf.

Recently, attempt has been made to link waqf with maqasid sharia'h. However, this linkage is basic and do not portray a picture of a broad vision. Somehow this also linked to the lack of full development of the doctrine of maqasid shari'ah. Nevertheless, if both concepts are developed further the aim of waqf may be broadened. The lack of transparency in our opinion may discourage future generations to contribute, as they would be unable to see how the institution of waqf can help Muslims in any tangible manner. Additionally, lack of transparency may encourage misuse of waqf funds or their mismanagement. Both may lead to the decrease of donations.

To conclude, the concept of perpetuity of waqf as mentioned above, indeed, has helped Muslims to benefit from the charity of the past generations. However, more than one billion Muslims still live in poverty, and most of their states are weak and dependent on the assistance of others. For this, sufficient waqf funds must be accumulated and put to a productive use so that sustainability of waqf would not be the main concern compared to how much of these funds are available for assisting the state and citizens. However, despite the latest achievements of some waqf organisations, their accumulated funds are insufficient. Therefore, the writers of this piece conclude that future efforts need to be made to develop the concept of waqf based on maqasid shari'ah while in tandem need to develop a universal, and comprehensive vision of shari'ah based on its objectives.

\section{References}

Abdel Mohsin, M.I. 2008. Cash Waqf a New Financial Product Model Aspect of Shari'ah Principles on Its Commercialization. Paper Presented at the Islamic Banking, Accounting and Finance Conference (iBAF 2008). Kuala Lumpur, 28-29 July.

Abu al-Fadl, Muhammad Ibn Manzur. 1982. Lisan al-'Arab. Vol. 6. Beirut: Dar Sadr.

Ahmad, Umar, Mohammad, Mustaf. Ogunbado \& Ahmad Faosiy. 2015. Examining the traditional waqf-based financing method and their implications for socio-economic development. Journal of Business and Management (IOSR)-JBM). 17 (2):119-125. www.iosrjournals.org. Retrieved:12 September 2020.

Ariff Hidayat, A. 2010. Waqf continued relevance as the third sector in terms of mobilizing resources for productive use in Islamic economic system. PhD Program Working Paper, INCEIF.

Ayub, H. 2003. Fiqh al-Muamalah al-Maliyah. Cairo: Dar al-Salam.

Babacan, Mehmet. 2011. Economics of philanthropic institution, regulation and governance in Turkey. Journal of Economic and Social Research. 13 (2): 61-89.

Cizakca, M. 2000. A History of Philanthropic Foundations: The Islamic World from the Seventh Century to the Present. Istanbul: Boğaziçi University Press.

Gil, M. 1998. The early waqf foundations. Journal of Near Eastern Studies. 57 (2):125-140.

Hakeem, Oladapo, B., Rahman, Oseni A. \& Omar, Mustafa Mohammed. 2016. A comparative analysis of waqf institution and endowment foundation: determinants of sustainability. International Journal of Novel Research in Humanity and Social Sciences. 3 (4): 151-162. (online) www.noveltyjournals.com. Retrieved: 12 November 2020.

Hamad, Nazih, 1993. Asalib al-Istithmar al-Awqaf wa Idarahtuh. In, Abhath Nadwah Nahwa Dawr Tamwil li al-Waqf. al-Kuwait: Wizarah al-Awqaf wa Shu'un al-Islamiyah. 
Hashim, Hydzulkifli, Omar, Ahmad, Umar \& Diara Md. Jadi. 2014. The development of waqf properties by using credit-based financing methods: a critical review and its implications to social welfare of the Ummah. Vol.1, Conference: Waqaf Iqlimi May 2014. At USIM, Nilai, Negeri Sembilan.

Hassan, N. Abdul-Rahman A. \& Yazid Z. 2018. Developing a new framework of waqf management. International Journal of Academic Research in Business and Social Sciences. 8 (2): 287-305.

Hisham, S. Hazel, Adria Jasiran \& Kamaruzaman Jusoff. 2013. Substitution of waqf properties in Malaysia: statutory provision and implementation. Middle East Journal of Scientific Research. (13): 23-27. DOI: 10.5829/idosi.mejsr.2013.13.1877.

Ibn Furat. 1939. Tarikh Ibn al-Furat. Q. Zurayq \& N. Izz al-Din. (ed.) 9 Vols. Beirut. n. p.

Ibn Qudamah, M. A. 1999. al-Mughni, Sa'udi Arabia: Dar `Alim al-Kutub

Ibrahim, Dahlia \& Ibrahim, Haslindar. 2013. Revival of the waqf properties in Malaysia. Paper Proceeding of the $5^{\text {th }}$ Islamic Economic System Conference (iECONS 2013) Sustainable Development Through the Islamic Economics System. Organised by Faculty of Economics and Muamalat, University Sains Islam Malaysia, Berjaya Time Suare Hotel, Kuala Lumpur, 4-5 $5^{\text {th }}$ September. 2013

Jasni, bin Sulong. 2013. Permissibility of istibdal in Islamic law and the practice in Malaysia. Journal of US-China Public Administration. 10 (7):680-689.

Kahf, M. 1998. Financing the development of awqaf property. Seminar on Development of Awqaf by Islamic Research and Training Institute (IRTI), Kuala Lumpur. (online) http://monzer.kahf.com/papers/english/financing_awqaf.pdf Retrieved: 26 November 2020.

al-Khassaf, a. b. 1904. Ahkam Al-Awqaf. Cairo: Diwan 'Umum al-Awqaf al-Misriyah.

Kuran, T. 2004. Why the Middle East is economically underdeveloped: historical mechanism of institutional stagnation. The Journal of Economic Perspectives. 18 (3):71-90.

M. Hoexter. 1995. Huquq Allah `an Huquq al-Ibad As Reflected in the Waqf Institution. Jerusalem Studies in Arabic and Islam. 19: 133-57.

M. Sharon. 1966. A Waqf Inscription from Ramlah. Arabica. 13: 77-78. N. L., N. P.

Maqrizi, Taqi Al-Din. 1943. Kitab al-Suluk li-Marifat Duwal al-Muluk. M. M. Ziyada And S. A. Ashur (Ed.). Vol. 3 Cairo: n.p.

Mardawi, A. S. A. 1956. Al-Insaf fi Ma'rifat al-Rajih Min al-Khilaf. Beirut: Dar Ihya' Al-Turath AlArabi.

Maya, Shatzmiller. 2000. The Berbers and the Islamic State. Princeton: Markus Weiner Publishers.

Mohd Ali, Norinah, Ahmad, Rubi \& Shahnaz, Nurul Ahmad Mahzan. 2015. The Need of An Effective Business Model for Waqf Land Development in Malaysia. 20th International Research Conferences on Business, Economics and Social Sciences. December 2015 At: Istanbul, Turkey. (Online) https://www.researchgate.net/publication/286863128_. Retrieved: 20 December 2020.

Mujir al-Din. 1928. Al-Uns al-Jalil bi-Tarikh al-Quds wa-l-Khalil. M. B. al-'Ulum. (ed.) 2 Vols. Najaf: n. p.

Shamsiah, Abdul Karim. 2010. Contemporary Shari'ah compliance structuring for the development and management of waqf assets in Singapore. Kyoto Bulletin of Islamic Area Studies. 3 (2):143-16.

Tahir, M. Sabit \& Abdul Hamid, Mar Iman. 2014. Waqf Property: Concept, Management, Development, and Financing. Johor: Penerbit UTM Press.

Tahir, M. Sabit \& Abdul Hamid Mar Iman. 2006. Obstacles of the current concept of waqf to the development of waqf properties and the recommended alternative. Malaysian Journal of Real Estate. 1(1): 27-38.

Tirmidhi, Muhammad B. Isa. 1967. Al-Jami' al-Sahih. Vol. 5. Medinah: Al-Maktabah al-Salafiyah.

Lev. Yaacov 2005. Charity Endowments and Charitable Institutions in Medieval Islam. US: University Press of Florida.

Zuhaiyli, W. 1997. al-Fiqh al-Islami Wa Adillatuh. Beirut: Dar al-Fikr. 